\title{
CHEMICAL DESULPHURISATION OF SUB-BITUMINOUS HIGH SULPHUR INDONESIAN COAL VIA PEROXYACETIC ACID TREATMENT
}

\author{
M.A.M. Ishak, K. Ismail* \\ School of Applied Sciences, Universiti Teknologi MARA, \\ Arau Campus, Perlis Branch, Perlis, Malaysia \\ M.A.M. Nawi \\ School of Chemical Sciences, Universiti Sains Malaysia, \\ Penang, Malaysia
}

\author{
A.F. Ismail \\ Department of Mechanical Engineering, \\ International Islamic University Malaysia, \\ Kuala Lumpur, Malaysia
}

Received 1 June 2002, Accepted 9 December 2002

\begin{abstract}
The chemical desulphurisation from an Indonesian high sulphur sub-bituminous Banjarmasin Haji Ali-Aliansar coal was investigated using the peroxyacetic acid (PAA), a mild oxidising agent. A mixture of hydrogen peroxide : acetic acid (i.e. $30: 70$ by volume ratio with $6 \%$ of hydrogen peroxide concentration) at $50^{\circ} \mathrm{C}$ of reaction temperature is capable of reducing the total sulphur content in the coal from $3.46 \%$ to $1.29 \%$ by weight, corresponding to the removal of up to $c a .72 \%$ of the total sulphur; both the inorganic (mainly pyrite) and organic sulphur forms, and approximately 10 to $44 \%$ of ashes in the coal. The simultaneous removal of both inorganic and organic sulphur forms was measured with respect to reagent volume mixed ratio, reaction temperature and hydrogen peroxide concentrations. The success of desulphurisation was measured by the reduction of the total sulphur content of the desulphurised product, its S/ $\mathrm{C}$ atomic ratios and ash yields of the treated coal. In general, all inorganic and some of the organic sulphur could be removed from the coal using mild conditions without severely affecting the coal microstructure as observed via the Scanning Electron Microscope with Energy Dispersive X-ray (SEM-EDX).
\end{abstract}

\section{INTRODUCTION}

The utilisation of coal for generating electricity in Malaysia has been increasing steadily from $11 \%$ in 1995 to about $33 \%$ by the year $2020^{1,2}$. Unfortunately, combustion of this abundant fuel

*Corresponding author-email: khudzir@pc.jaring.my 
creates environmental problems and one of the major problems associated with direct utilisation of coal is the emission of sulphur containing gases (mainly sulphur dioxide and sulphur trioxide) into the atmosphere ${ }^{3}$. Further, in view of the world energy crisis and with the gradual depletion of superior high quality low sulphur coal reserves, attention is being given to desulphurise the low-grade high sulphur coals from relatively large reserves to obtain environmentally acceptable clean fuels. Hence, in order for high sulphur coal to be utilised as clean fuel, the pretreatment processes of sulphur removal from coal have to be effective in order to remove the inorganic (pyrite) and organic sulphur forms.

The desulphurisation of coal prior to combustion is being carried out either by physical, chemical or biological methods. Physical methods are only capable of removing large pyritic particles. The biological techniques, however, are time-consuming with some of the bacteria specifically remove only certain types of sulphur forms. Most of the effective coal desulphurisation techniques are based on chemical methods whereby almost all the pyritic sulphur and substantial amount of organic sulphur being removed from the coal.

Various chemical desulphurisation techniques have been applied to coal and among these are the use of bases such as sodium carbonate ${ }^{4,5}$ and some organic bases (sodium methoxide, sodium butoxide and sodium benzoxide $)^{6,7}$. Recently, Balaz et al. ${ }^{8}$ reported the use of simultaneous grinding and alkaline chemical leaching process (GACL) on brown coal and found that more than $41 \%$ of total sulphur reduction was achieved. The GACL process, which was carried out in atmospheric pressure, was claimed to be of comparable to that of the high temperature molten caustic leaching (MCL) process.

An alternative method for chemical desulphurisation of coal is the use of oxidative reaction condition. Typical oxidising agents that have been applied to coal include hydrogen peroxide ${ }^{9}$, potassium permanganate ${ }^{10}$, chlorine ${ }^{11}$, and a number of other chemical oxidants. Although both potassium permanganate and chlorine are efficient desulphurising agents, however, these treatments were found to affect severely the coal microstructures and coking properties, respectively. In another work, Ahnonkitpanit et al. ${ }^{12}$ reported that almost complete removal of pyrite and sulphate sulphur with substantial reduction in ash were achieved by leaching the Mae Moh coal with hydrogen peroxide-sulphuric acid solution. Moreover, the work by Palmer et al. ${ }^{13}$ using peroxyacetic acid (mixtures of 30\% hydrogen peroxide with acetic acid) showed that about 40 to $60 \%$ of the total sulphur had been removed from the high sulphur Illinois Basin coals without affecting the coal properties severely. In addition, Borah et al. ${ }^{14}$ recently studied the effect of metal ions presence in the hydrogen peroxide solution towards organic sulphur removal, and found that both $\mathrm{Pd}^{2+}$ and $\mathrm{Sb}^{3+}$ ions enhanced the desulphurisation processes.

In this investigation, selective mild oxidation with peroxyacetic acid was used to study the desulphurisation of an Indonesian, Banjarmasin Haji Ali-Aliansar high sulphur sub-bituminous coal. Reaction variables studied include reagents volume mixed ratios, hydrogen peroxide concentrations and reaction temperatures. The effect of each variable on the desulphurisation of the coal was evaluated by measuring the total sulphur contents, the ash yield and the S/C atomic ratio of the desulphurised products. Further, Scanning Electron Microscope with Energy 
Dispersive X-ray (SEM-EDX) was carried out on the coal to observe if any micro-structural changes occur after the mild chemical treatments.

\section{EXPERIMENTAL}

\subsection{Coal Preparation}

The coal sample used in this study is a sub-bituminous Banjarmasin Haji Ali-Aliansar (BMHAA) originated from Kalimantan, Indonesia. Typically, the sample was pulverised and sieved through progressively finer screen to obtain particle sizes of 212 to $75 \mathrm{Um}$. Sieving was accomplished by shaking the ground coal in a Endecotts Shaker Model EFL2 MK3 for 30 minutes and was rendered moisture free (MF) by drying it in a vacuum oven at $40^{\circ} \mathrm{C}$ overnight and stored in a tightly screw cap bottle.

\subsection{Chemical Desulphurisation}

\section{Acid chromous chloride treatment}

The pyrite-free coal was obtained by removing the pyritic sulphur using the acidic chromous chloride reducing method ${ }^{15}$. The acidic chromous chloride was prepared via Jones reductor technique. The reactor setup consisted of a $500 \mathrm{~mL}$ three-neck flask equipped with a condenser, an additional funnel, a magnetic stirring bar and nitrogen inlet bubbler. About $2 \mathrm{~g}$ of coal in ethanol $(20 \mathrm{~mL})$ were added to the reactor flask with chromous chloride solution $(80 \mathrm{~mL})$ and concentrated hydrochloric acid $(40 \mathrm{~mL})$ contained in the additional funnel. The acidic chromous chloride solution was added dropwise with stirring under nitrogen flowing at a rate of $\sim 5$ bubble/s before heated to reflux for 2 hours. The mixture was then filtered and washed with hot distilled water.

\section{Peroxyacetic acid treatment}

Chemical desulphurisation was carried out according to the method described by Palmer et al. ${ }^{13}$ with some modifications. About $2 \mathrm{~g}$ of coal $(<250 \mu \mathrm{m})$ in $70 \mathrm{~mL}$ of glacial acetic acid and $30 \mathrm{~mL}$ of $6 \%$ hydrogen peroxide concentration were reacted at room temperature for a specific reaction time. The reaction mixture was cooled and the residual coal was filtered and washed with excess of hot distilled water and dried in vacuum oven set at $40^{\circ} \mathrm{C}$ overnight. The experiment was repeated at various reaction temperatures of 50 and $104^{\circ} \mathrm{C}$ (refluxing temperature). The reaction was also conducted with various acids to peroxide volume ratio of 50:50, 30:70 and 60:20 and with 30\% hyrogen peroxide concentration.

\subsection{Sample Analyses}

Ultimate analyses were done using Elemental Analyser Fision model 1108 with helium gas carrier. The percentage of oxygen was determined by difference. Proximate analyses for determination of moisture, volatile matter, fixed carbon and ash were carried out using 
Thermografic Analyser TG/DTA 220U System. The SEM-EDX analyses were carried out using a Leica Cambridge S360 with Camscan Editor ED4 Energy Dispersive Spectroscopy system with an accelerating voltage of $10 \mathrm{eV}$ using the spot mode.

\section{RESULTS AND DISCUSSION}

The ultimate and proximate analyses of this moisture free fresh and pyrite-free coal are summarised in Tables 1 and 2, respectively. The distribution of organic sulphur forms in this coal has been reported previously using high pressure temperature programmed reduction, and the results indicated that thiophenic groups are the dominant form of organic sulphur functionalities present $^{16}$.

Table 1 : Characterisation of fresh Banjarmasin Haji Ali-Aliansar (BMHAA) coal sample.

\begin{tabular}{|c|c|c|c|c|c|}
\hline \multicolumn{2}{|c|}{ Ultimate analysis (wt\% db) } & \multicolumn{2}{|c|}{ Proximate analysis (wt\%) } & \multicolumn{2}{|c|}{ Sulphur forms (wt\%) } \\
\hline Carbon & 68.00 & Moisture & 3.41 & Pyritic & 1.74 \\
\hline Hydrogen & 6.55 & Ash & 6.16 & Sulphate & 0.10 \\
\hline Nitrogen & 1.37 & Volatiles matter & 48.45 & Organic & 1.62 \\
\hline Sulphur & 3.46 & Fixed carbon & 41.98 & & \\
\hline Oxygen (by difference) & 20.62 & & & & \\
\hline $\mathrm{S} / \mathrm{C}$ atomic ratio $\left(10^{-4}\right)$ & 191 & & & & \\
\hline Calorific value $\left(\mathrm{MJ} \mathrm{kg}^{-1}\right)$ & 13.27 & & & & \\
\hline
\end{tabular}

Table 2 : Characterisation of pyrite-free Banjarmasin Haji Ali-Aliansar (BMHAA) coal sample.

\begin{tabular}{|c|c|c|c|}
\hline \multicolumn{2}{|c|}{ Ultimate analysis (wt\% db) } & \multicolumn{2}{|c|}{ Proximate analysis (wt\%) } \\
\hline Carbon & 71.24 & Moisture & 2.75 \\
\hline Hydrogen & 7.58 & Ash & 4.75 \\
\hline Nitrogen & 0.51 & Volatiles matter & 46.15 \\
\hline Sulphur & 1.76 & Fixed carbon & 46.35 \\
\hline Oxygen (by difference) & 18.91 & & \\
\hline $\mathrm{S} / \mathrm{C}$ atomic ratio $\left(10^{-3}\right)$ & 9.26 & & \\
\hline
\end{tabular}

\subsection{Coal Desulphurisation}

\section{Effect of reagent volume mixed ratios}

The enhancement of desulphurisation should be interpreted carefully since the addition of oxygen upon oxidation dilutes the remaining sulphur and would result in lower sulphur contents in the coal. Hence, one way to determine the effect of desulphurisation is to compare the S/C atomic ratio of the desulphurised coal with the untreated fresh coal. 
The treatments of BMHAA coal with acidic chromous chloride, glacial acetic acid and 6\% hydrogen peroxide alone (both reactions at $50^{\circ} \mathrm{C}$ ) were carried out and the results are shown in Table 3. It seems that both the acidic chromous chloride and acetic acid alone were able to reduce the total sulphur from 3.46 to $1.76 \%$ by weight, corresponding to $c a$. $52 \%$ of the total sulphur removal from the coal. Our previous study with acidic chromous chloride treatment on sub-bituminous Mukah Balingian Malaysian coal has shown that mainly pyritic sulphur is being removed by this treatment ${ }^{15}$. Hence, the results of desulphurisation using $6 \%$ hydrogen perox-

Table 3 : Analyses (wt\% dry basis) of treated BMHAA coal sample with chromous chloride, acetic acid and hydrogen peroxide alone at $50^{\circ} \mathrm{C}$ for 24 hours reaction time.

\begin{tabular}{lccc}
\hline \multicolumn{1}{c}{ Reagent } & $\begin{array}{c}\text { \% Ash } \\
\text { removed }\end{array}$ & $\begin{array}{c}\text { \% Sulphur } \\
\text { content }\end{array}$ & $\begin{array}{c}\text { \% Sulphur } \\
\text { total } \\
\text { removed }\end{array}$ \\
\hline Chromous chloride & 23 & 1.76 & 52 \\
Acetic acid & 22 & 1.76 & 52 \\
$6 \%$ hydrogen peroxide & 25 & 2.02 & 45 \\
\hline
\end{tabular}

ide concentration and glacial acetic acid alone (see Table 3) on the fresh coal at reaction temperature of $50^{\circ} \mathrm{C}$ reveal that these reagents are only capable of removing mainly the pyritic sulphur.

Table 4 : Effect of various reagents volume mixed ratio of acetic acid and 6\% hydrogen peroxide at various temperature for 24 hour reaction time on the desulphurisation of : (A) fresh and (B) pyrite-free BMHAA coal.

\begin{tabular}{|c|c|c|c|c|c|c|}
\hline \multirow[b]{2}{*}{$\begin{array}{l}\text { Reagent volume } \\
\text { mixed ratio } \\
\mathrm{CH}_{3} \mathrm{COOH}: \mathrm{H}_{2} \mathrm{O}_{2} \\
\end{array}$} & \multicolumn{3}{|c|}{ (A) Fresh BMHAA coal } & \multicolumn{3}{|c|}{ (B) Pyrite-free BMHAA coal } \\
\hline & $\begin{array}{c}\% \text { Ash } \\
\text { removed }\end{array}$ & $\begin{array}{c}\text { \% Sulphur } \\
\text { content }\end{array}$ & $\begin{array}{c}\text { \% Sulphur } \\
\text { total } \\
\text { removed }\end{array}$ & $\begin{array}{c}\% \text { Ash } \\
\text { removed }\end{array}$ & $\begin{array}{c}\text { \% Sulphur } \\
\text { content }\end{array}$ & $\begin{array}{c}\% \text { Sulphur } \\
\text { total } \\
\text { removed }\end{array}$ \\
\hline Fresh untreated & - & 3.46 & - & 23 & 1.76 & 52 \\
\hline \multicolumn{7}{|l|}{ Reaction at $28^{\circ} \mathrm{C}$} \\
\hline $30 \mathrm{~mL}: 70 \mathrm{~mL}$ & 11 & 1.57 & 51 & 22 & 1.49 & 53 \\
\hline $50 \mathrm{~mL}: 50 \mathrm{~mL}$ & 13 & 2.04 & 43 & 18 & 1.49 & 55 \\
\hline $70 \mathrm{~mL}: 30 \mathrm{~mL}$ & 10 & 1.69 & 52 & 22 & 1.63 & 54 \\
\hline \multicolumn{7}{|l|}{$\underline{\text { Reaction at } 50^{\circ} \mathrm{C}}$} \\
\hline $30 \mathrm{~mL}: 70 \mathrm{~mL}$ & 10 & 1.69 & 54 & 25 & 1.41 & 59 \\
\hline $50 \mathrm{~mL}: 50 \mathrm{~mL}$ & 19 & 1.94 & 44 & 31 & 1.43 & 58 \\
\hline $70 \mathrm{~mL}: 30 \mathrm{~mL}$ & 32 & 1.29 & 62 & 44 & 0.95 & 72 \\
\hline \multicolumn{7}{|c|}{$\underline{\text { Reaction at } 104^{\circ} \mathrm{C}}$ ( 1 hour $)$} \\
\hline $30 \mathrm{~mL}: 70 \mathrm{~mL}$ & 22 & 2.04 & 49 & 38 & 1.63 & 54 \\
\hline $70 \mathrm{~mL}: 30 \mathrm{~mL}$ & 23 & 1.74 & 48 & 38 & 1.49 & 53 \\
\hline
\end{tabular}


Table 4 shows the effect of various reagents mixed ratio with $6 \%$ peroxide-acetic acid treatments on the fresh and pyrite-free coal at 28,50 and $104^{\circ} \mathrm{C}$ (refluxing temperature) for 24 hour of reaction time.

In all reaction conditions, the desulphurisations on the fresh coal show a total sulphur reduction in the range of $43-62 \%$, with the highest percentage of total sulphur removal of $c a$. $62 \%$ being achieved with reagent volume mixed ratio of $70: 30\left(\mathrm{CH}_{3} \mathrm{COOH}: \mathrm{H}_{2} \mathrm{O}_{2}\right)$ at $50^{\circ} \mathrm{C}$. Moreover, to ascertain the effectiveness of these reagents volume mixed ratio to remove the organic sulphur forms, the pyrite was removed from the coal sample prior to the PAA reaction via acid chromous chloride treatment. Apparently, the results of $6 \%$ peroxide-acetic acid treatments on the pyritefree coals (see Table 4) show a further 2 to $10 \%$ of total sulphur reduction being achieved, which accounted for about 4 to $42 \%$ of organic sulphur removal. Thus, the sulphur removal obtained after the chromous chloride mild reducing treatment is found to be substantially additive. Hence, these observations seem to show that the ability of these reagents to remove both the inorganic (pyrite) and organic sulphur forms. Likewise, the mechanism involved in the removal of sulphur in the coal remains uncertain due to inadequate knowledge with regards to the type of organic sulphur forms present in the coal. However, for the organic sulphur to be removed completely from the coal, the carbon-sulphur (C-S) bonds need to be broken. Thus, it is anticipated that the remaining organic sulphur forms that are still present in the coal are probably of the thiophenic types, with the C-S bonds cease to be cleavage by the reagent ${ }^{13}$.

\section{The Effect of Hydrogen Peroxide concentrations}

Table 5 shows the results of $30 \%$ peroxide-acetic acid treatments on the fresh and pyrite-free coal with various reagent volume mixed ratios at 28 and $50^{\circ} \mathrm{C}$ for 24 hour of reaction time.

Obviously, the results obtained after treatments with $30 \%$ peroxide-acetic acid (both at 28 and $50^{\circ} \mathrm{C}$ ) show a slight increased in the total sulphur removal of the coal, and are comparable to

Table 5 : Effect of 30\% hydrogen peroxide concentration at various temperature for 24 hour reaction time on the desulphurisation of : (A) fresh and (B) pyrite-free BMHAA coal.

\begin{tabular}{|c|c|c|c|c|c|c|}
\hline \multirow[b]{2}{*}{$\begin{array}{l}\text { Reagent volume } \\
\text { mixed ratio } \\
\mathrm{CH}_{3} \mathrm{COOH}: \mathrm{H}_{2} \mathrm{O}_{2}\end{array}$} & \multicolumn{3}{|c|}{ (A) Fresh BMHAA coal } & \multicolumn{3}{|c|}{ (B) Pyrite-free BMHAA coal } \\
\hline & $\begin{array}{c}\% \text { Ash } \\
\text { removed }\end{array}$ & $\begin{array}{c}\% \text { Sulphur } \\
\text { content }\end{array}$ & $\begin{array}{c}\text { \% Sulphur } \\
\text { total } \\
\text { removed }\end{array}$ & $\begin{array}{c}\% \text { Ash } \\
\text { removed }\end{array}$ & $\begin{array}{c}\text { \% Sulphur } \\
\text { content }\end{array}$ & $\begin{array}{l}\% \text { Sulphur } \\
\text { total } \\
\text { removed }\end{array}$ \\
\hline \multicolumn{7}{|l|}{ Reaction at $28^{\circ} \mathrm{C}$} \\
\hline $50 \mathrm{~mL}: 50 \mathrm{~mL}$ & - & - & - & 38 & 1.56 & 55 \\
\hline $60 \mathrm{~mL}: 20 \mathrm{~mL}$ & 23 & 1.49 & 53 & 38 & 1.49 & 55 \\
\hline \multicolumn{7}{|l|}{$\underline{\text { Reaction at } 50^{\circ} \mathrm{C}}$} \\
\hline $60 \mathrm{~mL}: 20 \mathrm{~mL}$ & 29 & 1.48 & 56 & 33 & 1.35 & 58 \\
\hline $70 \mathrm{~mL}: 30 \mathrm{~mL}$ & 21 & 1.32 & 57 & 38 & 1.69 & 52 \\
\hline
\end{tabular}


that obtained using $6 \%$ peroxide-acetic acid. Hence, these findings showed that the increase in the hydrogen peroxide concentration from 6 to $30 \%$ did not significantly improve the total sulphur removal of the coal.

\section{Effect of Reaction Temperature}

The direct PAA treatments using the $6 \%$ peroxide-acetic acid on the fresh coal at 28, 50 and $104^{\circ} \mathrm{C}$ show total sulphur reduction of 3.46 to $1.29 \%$ which account to $\sim 62 \%$ of sulphur (mainly pyritic) being removed from the coal (see Table 4). An exception is with the $50^{\circ} \mathrm{C}$ of reaction temperature whereby some organic sulphur forms $(\sim 21 \%)$ is being removed from the coal. Interestingly, the results for desulphurisation with PAA on the fresh coal sample at elevated temperature $\left(104^{\circ} \mathrm{C}\right)$ gave a lower amount of sulphur removal than the PAA treatment on the

Percent total sulphur removed

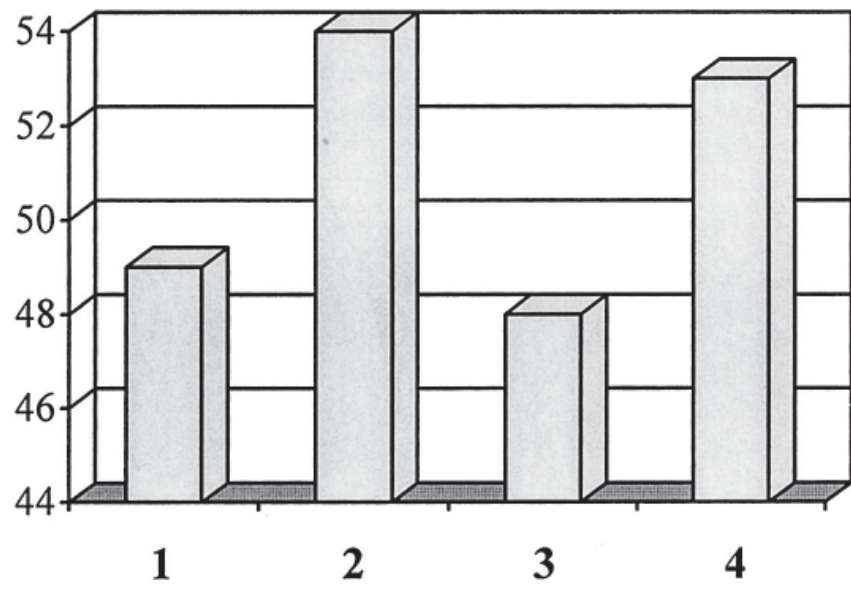

$1=(30 \mathrm{~mL}: 70 \mathrm{~mL})$ on fresh.

$2=(30 \mathrm{~mL}: 70 \mathrm{~mL})$ on pyrite-free.

$3=(70 \mathrm{~mL}: 30 \mathrm{~mL})$ on fresh.

$4=(70 \mathrm{~mL}: 30 \mathrm{~mL})$ on pyrite-free.

$\left(\mathrm{CH}_{3} \mathrm{COOH}: 6 \% \mathrm{H}_{2} \mathrm{O}_{2}\right)$

Coal samples with reagent mixture ratios.

Figure 1: Percentages of total sulphur removed of fresh and PAA pyrite-free coal samples at elevated reaction temperature $\left(104^{\circ} \mathrm{C}\right)$.

pyrite-free coal (see Figure 1 and Table 4). This observation might due to the simultaneous increase in the amount of sulphate sulphur as a result of rapid pyrite oxidation with increasing reaction temperature on the fresh coal. The iron sulphate that was formed was not completely dissolved by the solvent system and water washing, and thus remains intact within the coal matrix. This contributes to the increase in the sulphur content of the treated coal.

Moreover, the rapid dissolution and desulphurisation reactions at elevated temperature of $104^{\circ} \mathrm{C}$ might also have resulted to an insufficient time for the reagent to diffuse into the coal microstructures. If this notion is true, then the overall reaction at higher temperature will be dominated by reactions at the surface of the coal particles and the mass transport limitations will be observed. Consequently, this might explain the huge reduction in the pyritic sulphur in the coal since the pyrite is incorporated within the coal microstructures. In addition, the increase 
in the reaction temperature also leads to more coal degradation and solubilisation, as observed by the darkening of the filtrate. This, however, will affect the overall yield and heating value of the desulphurised coal. Hence, it is therefore important to balance between the amounts of sulphur removed and coal dissolved.

\subsection{Effect of PAA Treatments on the Microstructure of the Coal}

The effect of PAA treatments on the microstructure of the coal under different set of reaction temperature are displayed in Figures 2-5, allowing comparison between the fresh and treated samples. Obviously, the SEM micrographs for the treated coal samples (see Figures 3, 4 and 5 ) indicate some noticeable physical alteration with appearance of hollow pits at the surface predominantly with 50 and $104^{\circ} \mathrm{C}$ of reaction temperatures. These observations are probably due to the disappearance of pyrite and dissolution of some mineral matters from the surface of the coal as results of the mild oxidizing treatment. Further, it seems that the influence of heat might have induced the fragmentation of the coal surfaces as can be seen with higher temperature regime. The high degree of desulphurisation obtained by the oxidant with increasing reaction temperature suggests that the reduction in the particle size and increased in porosity are

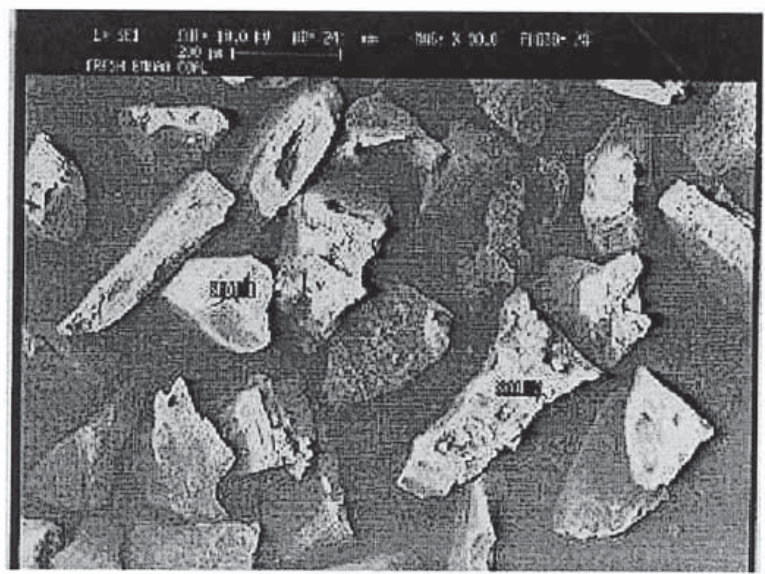

Figure 2 : SEM micrograph of fresh untreated BMHAA coal sample.

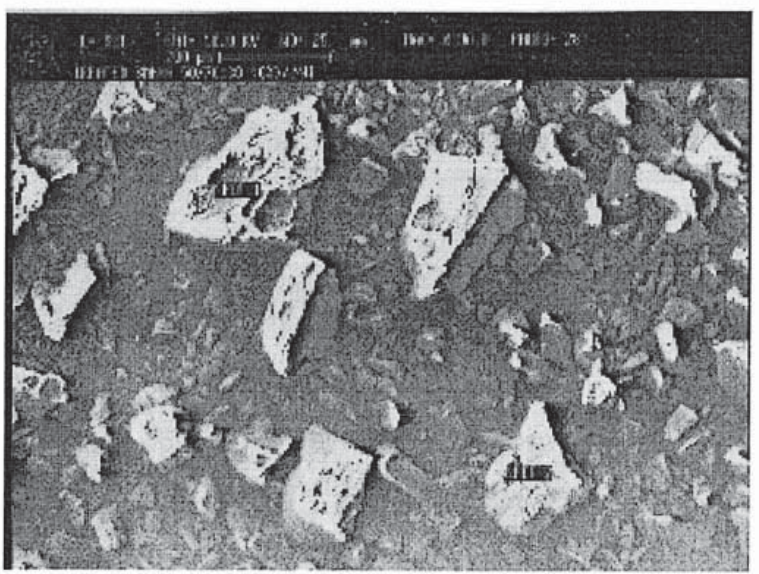

Figure 4 : SEM micrograph of treated BMHAA coal with $\mathrm{PAA}\left(6 \% \mathrm{H}_{2} \mathrm{O}_{2}\right)$ at $50^{\circ} \mathrm{C}$ for 24 hours.

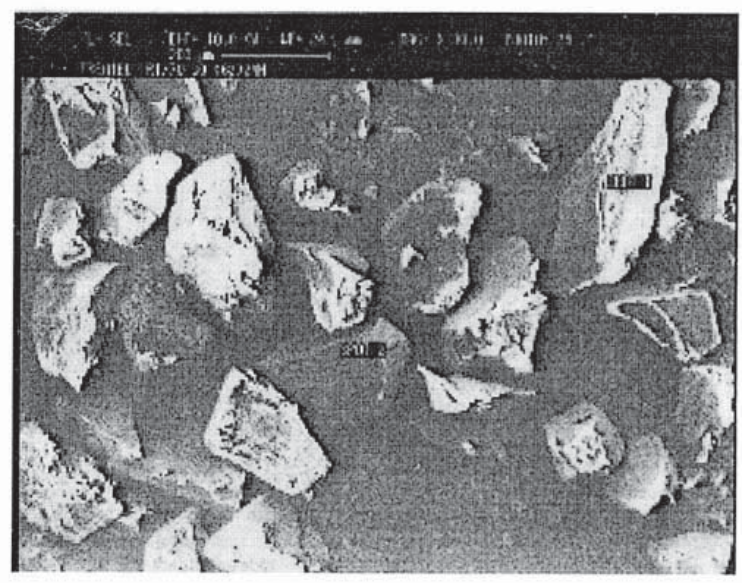

Figure 3 : SEM micrograph of treated BMHAA coal with $\mathrm{PAA}\left(6 \% \mathrm{H}_{2} \mathrm{O}_{2}\right)$ at $28{ }^{\circ} \mathrm{C}$ for 24 hours.

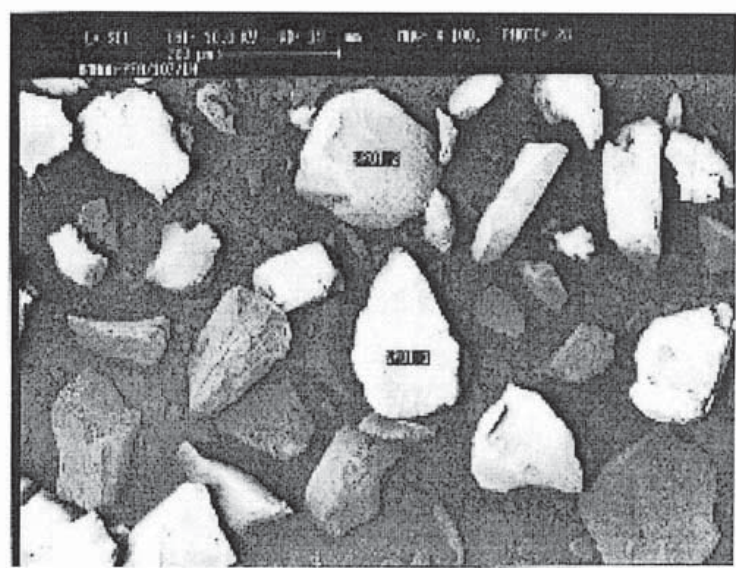

Figure 5 : SEM micrograph of treated BMHAA coal with $\mathrm{PAA}\left(6 \% \mathrm{H}_{2} \mathrm{O}_{2}\right)$ at $104{ }^{\circ} \mathrm{C}$ forl hour. 
necessary for the reagent to penetrate through the coal structure and consequently the organic matrix.

\subsection{Ash Reduction}

The ash yields of the treated coal are summarised in Tables 4 and 5. The overall results obtained indicate $\mathrm{ca} .10$ to $44 \%$ of ash reduction was achieved in the treated coal and is prominent with PAA pyrite-free sample. This observation is to be expected since some of the ash had been removed from the pyrite-free coal during the acidic chromous chloride treatment that was carried out prior to peroxyacetic-reaction. Furthermore, a comparison between the EDX spectra for the fresh and PAA $\left(6 \% \mathrm{H}_{2} \mathrm{O}_{2}\right)$ treated coal samples at $50^{\circ} \mathrm{C}$ of reaction temperature (see Figures

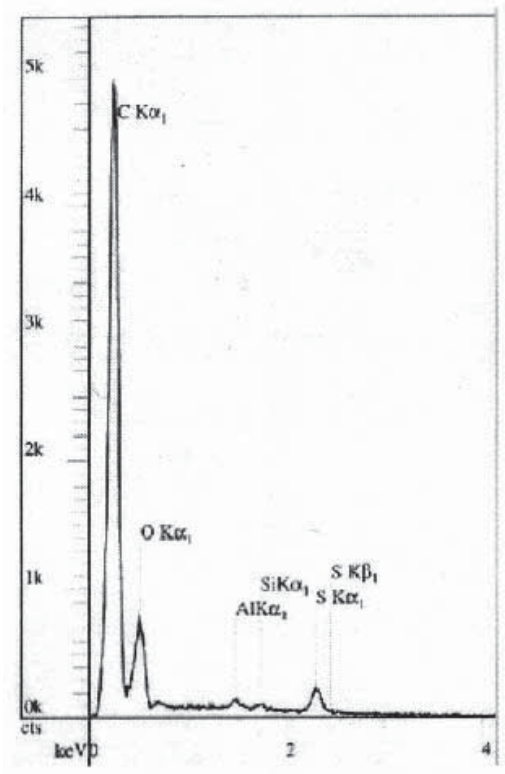

Figure 6: EDX spectrum of fresh Untreated BMHAA coal sample.

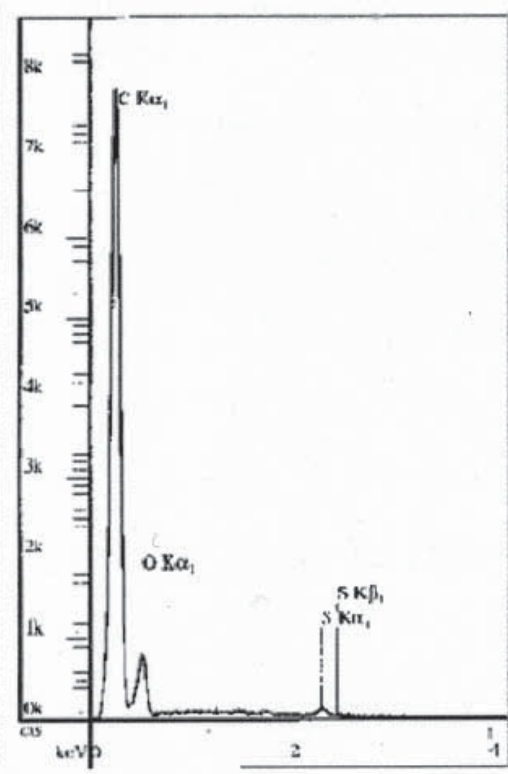

Figure 7 : EDX spectrum of treated BMHAA coal with $\mathrm{PAA}\left(6 \% \mathrm{H}_{2} \mathrm{O}_{2}\right)$ at $50{ }^{\circ} \mathrm{C}$ for 24 hours.

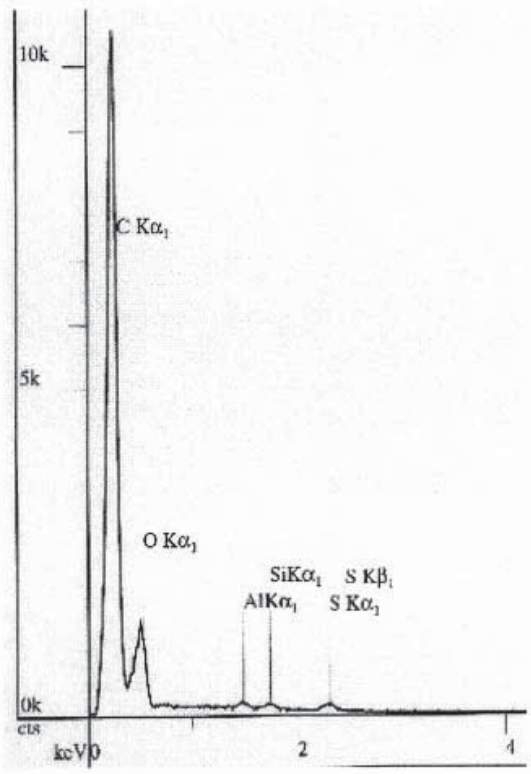

Figure 8 : EDX spectrum of treated BMHAA coal with $P A A$ $\left(6 \% \mathrm{H}_{2} \mathrm{O}_{2}\right)$ at $104{ }^{\circ} \mathrm{C}$ for 1 hour.

6 and 7) reveals generally reduced levels of the elements, mainly silica ( $\mathrm{Si}$ ), aluminium (Al) and sulphur (S), and are consistent with the results of ash removal as shown in Table 2. The EDX spectra for the PAA treated coal samples at $104^{\circ} \mathrm{C}$ of reaction temperature (see Figure 8), however, show little presence of these elements (i.e. silica ( $\mathrm{Si}$ ), aluminium (Al) and sulphur (S)) and are comparable with the low sulphur and low percent of ash removal by this treatment as indicated in Table 4.

\section{CONCLUSIONS}

The PAA mild oxidizing agents, i.e. both the 6 and 30\% peroxide with acetic acid mixtures at reaction temperatures of 28,50 and $104^{\circ} \mathrm{C}$ have found to be able to reduce inorganic (mainly pyrite) and organic sulphur forms to a certain extend, with substantial amount of de-ashing from 
BMHAA sub-bituminous coal. Further, the SEM micrographs demonstrate a clear effect of the PAA treatment on the coal surfaces, whereby minor alteration to the coal microstructures with increase in surfaces fragmentation and porosity are being observed especially at $50^{\circ} \mathrm{C}$ of reaction temperature, and is consistence with the high degree of desulphurisation being achieved. The EDX spectra for the PAA $\left(6 \% \mathrm{H}_{2} \mathrm{O}_{2}\right)$ at $50^{\circ} \mathrm{C}$ of reaction temperature show reduced level of the elements ( $\mathrm{Si}, \mathrm{Al}$ and $\mathrm{S}$ ) and are comparable to the high level of total sulphur and ash removal in the coal.

\section{ACKNOWLEDGEMENT}

The research was funded by the Bureau of Research and Consultancy, Universiti Teknologi MARA (Grant No. 600-BRC.ST.5/3/248) and Tenaga Nasional Research \& Development (TNRD) which supplied the coal sample.

\section{REFERENCES}

1. Anaz, M.(1995), Malaysia Seeking Clean Coal Technology. The Star. (May 18).

2. Omar, Z.(1994), The Global Power Exhibition and Conference for Asia. pp. 39.

3. Manahan, S.E.(1970), “Environmental Chemistry', pp. 358-361, Willard Grant Press; Boston.

4. Wheelock, T.D.(1981), Chem. Eng. Communication, 12, p. 137.

5. Chuang, K.C., Markuszewski, R., and Wheelock, T.D.(1983), Fuel Processing Technology, 7, p. 43.

6. Mazumder, B., Saikia, P.C., Sain, B., Baruah, B.P., and Bordoloi, C.S. (1989), Desulphurisation of High-Sulphur Coals of North-East Indian Coalfields by Organometallic Compounds, Fuel, 68, p. 610.

7. Prasassarakich, P., and Thaweesri, T.(1996), Kinetics of Coal Desulphurisation with SOdium Benzoxide, Fuel, 7, p. 816.

8. Balaz, P., LaCount, R.B., Kern, D.G., and Turcaniova, L.(2001), Chemical Treatment of Coal by Grinding and Aqueous Caustic Leaching, Fuel, 80, p. 665.

9. Ali, A., Sunil, K.S., and Haque, R. (1992), Chemical Desulphurisation of High Sulphur Coals, Fuel, 71, p. 835.

10. Attia, Y.A., and Weiwen, L. (1987), 'Processing and Utilisation of High Sulphur Coal II’ (Eds. Chugh, Y.P., and Caudle, R.D.), p. 202, Elsevier, New York.

11. Sain, B., Saikia, P.C., Baruah, B.P., Bordoloi, C.S., and Mazumder, B. (1991), Fuel, 70, p. 753.

12. Ahnonkitpanit, E., and Prasassarakich, P.(1989), Coal Desulphurisation in Aqueous Hydrogen Peroxide, Fuel, 68, p. 819.

13. Palmer, S.R., Hippo, E. J., and Dorai, X.A.(1994), Chemical Coal Cleaning Using Selective Oxidation, Fuel, 73, p. 161.

14. Borah, D., Baruah, M.K., and Haque, I. (2001), Oxidation of High Sulphur Coal. Part 2. Desulphurisation of Organic Sulphur by Hydrogen Peroxide in Presence of Metal Ions, Fuel, 80, p. 1475.

15. Ismail, K., Kamal, M.L., Ishak, M.A.M., Zakaria, Z., Majid, K.A., and Hassan, H. (1996), Depyritisation on Malaysian Coals Using Chemical Approaches. Proc. 12th. Symposium of Malaysian Chemical Engineers, UKM, Bangi, p. 267. 